\title{
OESTRUS-ACCELERATING PHEROMONE OF MICE: ASSAY, ANDROGEN-DEPENDENCY AND PRESENCE IN BLADDER URINE
}

\author{
F. H. BRONSON AND W. K. WHITTEN \\ The Jackson Laboratory, Bar Harbor, Maine, U.S.A.
}

(Received 30th May 1967)

\begin{abstract}
Summary. Two methods for the assay of a pheromone produced by male mice were compared. Using these methods it was shown that the pheromone was present in urine from males of two inbred strains and from androgenized, spayed females, but not in urine from castrate males. It was present in urine collected directly from the bladder free from any accessory gland secretion.
\end{abstract}

All-female grouping of laboratory mice is often accompanied by a suppression of oestrous cycles. Exposure to the presence of a male results in both an induction and an acceleration of cycling and, hence, usually leads to a synchrony of oestrus among the members of a group (Whitten, 1958). This action of a male is independent of visual, auditory or tactile stimulation and, therefore, has been postulated as taking the form of an olfactory-mediated pheromone (Whitten, 1959, 1966 and unpublished material). Support for the pheromone hypothesis was noted when Marsden \& Bronson (1964) mimicked the effect of a male by using only topical exposure to male urine. Finally, Bruce (1965) reported the loss of a male's capacity to influence oestrous cycles following castration, thus indicating the androgen-dependency of the pheromone.

The present study was initiated with three objectives: (1) to obtain an efficient assay of the urinary pheromone, (2) to confirm that its production is androgen-dependent, and (3) to determine if the pheromone is present in bladder urine before the addition of secretions from such accessory structures as the bulbo-urethral glands, the urethral diverticulum or the preputial glands.

Female mice of either the $129 / \mathrm{J}$ or SJL/J strains were raised in groups of four until 70 days of age, at which time they were housed six to ten/cage $(6 \times 6 \times 12$ in., stainless steel $)$ and exposed to urine from various sources in a male-free room. Urine was delivered to the females' cages either by the use of drip cages containing other mice (Expt. 1) or by way of syringes driven by an infusion pump (Expt. 2; Dominic, 1966). Drip cages were $6 \times 12 \times 6$ in. galvanized steel with funnel-shaped bottoms that terminated in 5 in. stainless steel tubes. These tubes penetrated the tops of cages of experimental females, allowing urine to drip on to their bedding. Two layers of screening, one coarse and one fine, served as flooring and also prevented faeces from reaching the lower cages. Animals living in drip cages were removed and allowed to 
feed for $4 \mathrm{hr}$ each morning, but water was available to them at all times. The effect of urine exposure in both experiments was evaluated in terms of relative frequency of vaginal oestrus. Groups of females were tested with more than one treatment but a minimum of 3 weeks was always maintained between such tests.

Experiment 1. The presence of a male or his urine acts both to initiate oestrous cycles and to decrease their average length. An assay procedure based on vaginal smearing during the 3rd and 4th days after urine exposure begins should detect those mice in which oestrus was successfully induced while observation over a 6-day period (Days 3 to 8 ) should reveal an additional number of mice whose second cycles were shortened. Thus, the longer period of observation may provide a more sensitive assay but at the expense of considerably more work and a less efficient use of animals and space. In this experiment the relative efficiency of these two alternatives was evaluated as was the androgen-dependency of the urinary pheromone. The basic procedure was to house $129 / \mathrm{J}$ females (six or seven/cage) under drip cages containing one of four types of animals: (1) intact C57BL/6J males, (2) C57BL/6J males castrated as adults (testing took place 4 months after castration), (3) ovariectomized G57BL/6J females bearing 20-mg testosterone implants, or (4) intact

\section{TABLE 1}

DATA FROM OBSERVATIONS OF VAGINAL SMEARS OBTAINED EITHER ON DAYS 3 AND 4 OR ON DAYS 3 TO 8 (AFTER INITIATION OF URINE EXPOSURE) FROM 129/J MICE HOUSED UNDER DRIP GAGES

\begin{tabular}{l|c|c|c|c}
\hline \multicolumn{1}{c|}{ Urine source } & $\begin{array}{c}\text { No. females } \\
\text { tested }\end{array}$ & $\begin{array}{c}\text { No. in } \\
\text { oestrus on } \\
\text { Days } 3 \text { or } 4\end{array}$ & $\begin{array}{c}\% \text { in } \\
\text { ostrus on } \\
\text { Days } 3 \text { or } 4\end{array}$ & $\begin{array}{c}\text { Mean frequency of } \\
\text { oestrus during } \\
\text { Days } 3 \text { to } 8( \pm S . E .)\end{array}$ \\
\hline No urine & 62 & 19 & 31 & $0 \cdot 87 \pm 0.07$ \\
Castrate C57BL/6J males & 21 & 9 & 43 & $0 \cdot 86 \pm 0 \cdot 14$ \\
Intact C57BL/6 J males & 33 & 26 & 79 & $1.40 \pm 0 \cdot 12$ \\
Androgenized C57BL/6J females & 14 & 8 & 57 & $1.43 \pm 0 \cdot 17$ \\
Intact C3H/J males & 27 & 19 & 70 & $1 \cdot 48 \pm 0.11$ \\
\hline
\end{tabular}

$\mathrm{C} 3 \mathrm{H} / \mathrm{J}$ males. Five of each type of test animal were used in each drip cage. Vaginal smears were obtained from all females on Days 3 to 8 inclusive.

The oestrus-inducing effectiveness of urine was highly dependent upon the presence of a testicular or implanted androgen source (Table 1). Data from Days 3 and 4 resulted in only two differences being significant (no urine control versus exposure to urine from intact $\mathrm{C} 57 \mathrm{BL} / 6 \mathrm{~J}$ or $\mathrm{C} 3 \mathrm{H} / \mathrm{J}$ males; $P<0.01)$. The levels of significance with 3 to 8 days' observations, however, were increased in all cases to 0.01 except in reference to the difference between castrate males and androgenized females $(P<0 \cdot 05)$.

Experiment 2. This experiment was designed to compare the pheromone content of bladder urine with that voided to the exterior. Bladder urine was collected fresh each morning from males in which the urethra had been ligated at its internal orifice during the preceding afternoon. Fresh external urine was collected by holding males over a Plexiglas plate and compressing the bladder through the abdominal wall. In the first series of tests $5 \mathrm{ml}$ of urine collected 
from mature C.57BL/6J males was mixed with $5 \mathrm{ml}$ of water containing an antioxidant (propyl gallate) and antibiotic (Achromycin, Lederle Laboratories) and delivered to the cages from an infusion pump (Dominic, 1966). A timing device allowed the mixture described above to be delivered at the rate of a single $0.2 \mathrm{ml}$ aliquot every half-hour. In a second series of tests, $8 \mathrm{ml}$ of urine were collected from $\mathrm{C} 57 \mathrm{BL} / 6 \mathrm{~J}$ and hybrid $129 / \mathrm{J} \times \mathrm{C} 57 \mathrm{BL} / 6 \mathrm{~J}$ males in a $1: 1$ ratio, mixed with an additional $3 \mathrm{ml}$ of antioxidant-antibiotic mixture, and delivered in single aliquots of $0.46 \mathrm{ml}$ every hour. $\mathrm{SJL} / \mathrm{J}$ females, grouped nine to ten/cage, were exposed to urine for 3 consecutive days with vaginal smears obtained on the 3rd and 4th mornings.

Exposure to male mouse urine again resulted in a significantly higher incidence of oestrus $\left(P<0.001\right.$ in all cases; $\chi^{2}$; Table 2$)$. Bladder urine was as effective as externally collected urine in inducing oestrus. Control levels of 22 and $25 \%$ were raised to 48 and $50 \%$ for external and bladder urine, respectively, in the first series of tests and to 60 and $63 \%$ during the second series.

TABLE 2

FREQUENCY OF OESTRUS IN SJL/J MICE ON DAYS 3 AND 4 AFTER INITIATION OF EXPOSURE TO MALE URINE GOLLECTED EITHER EXTERNALLY OR FROM THE BLADDER

\begin{tabular}{l|l|c|c}
\hline \multirow{2}{*}{$\begin{array}{c}\text { Urine source, } \\
\text { amount } / 24 \mathrm{hr}\end{array}$} & \multicolumn{3}{|c|}{ No. females in oestrus/No. females exposed to: } \\
\cline { 2 - 4 } & Nothing & $\begin{array}{c}\text { External } \\
\text { urine }\end{array}$ & $\begin{array}{c}\text { Bladder } \\
\text { urine }\end{array}$ \\
\hline C57BL/6J males, $5 \mathrm{ml}$ & $22 / 100$ & $48 / 99$ & $25 / 50$ \\
Mixed males, $8 \mathrm{ml} *$ & $17 / 67$ & $30 / 50$ & $19 / 30$ \\
\hline
\end{tabular}

* Urine from C57BL/6J and hybrid (C57BL/6 J × 129/J) males mixed 1:1.

As an additional control, thirty SJL females were exposed to human male urine under these conditions; five of these females $(17 \%)$ came into oestrus during the 2-day period, comparing well with frequencies obtained from control (no urine) treatment. This result supports the conclusion reached by Marsden \& Bronson (1965) that these pheromones are probably species specific.

Urine from males is known to function in two pheromonal capacities among laboratory mice: blocking of implantation because of an inhibition of prolactin release and in the induction and acceleration of oestrous cycles (reviewed by Bruce, 1966; Whitten, 1966). Whether these two functions are due to the same or different urinary factors is still unclear (Bronson, 1967). The two phenomena are markedly similar in their androgen-dependency and in that urine from gonadectomized females bearing androgen implants is effective in both cases (Dominic, 1965, 1966, present data). The present experiments also demonstrate that, at least for the oestrus-accelerating factor, bladder urine is as potent as externally collected urine, thereby ruling out the necessity of addition of factor(s) to urine after it leaves the bladder.

The study of urinary fractions for the purpose of progressive isolation of the oestrus-accelerating factor appears to be amenable to a 2-day assay using $\mathrm{SJL} / \mathrm{J}$ females. $129 / \mathrm{J}$ females responded well to urine delivered by the use of 
drip cages in a 6-day assay but less well for 2 days. Unreported pilot studies similar to Expt. 2 showed the SJL/J female to be more responsive than the $129 / \mathrm{J}$ for this type of assay.

This investigation was supported by Public Health Service Research Grants HD-00767 and HD-00473 from the National Institute of Child Health and Human Development, National Institutes of Health. The principles of laboratory animal care as suggested by the Council of the American Physiological Society are observed in this laboratory.

\section{REFERENCES}

Bronson, F. H. (1967) Pheromonal influences on mammalian reproduction. In: Perspectives in Reproduction and Sexual Behavior: a Memorial to Wm. C. Young. Ed. M. Diamond. Indiana University Press (in press).

Bruce, H. M. (1965) The effect of castration on the reproductive pheromones of male mice. 7 . Reprod. Fert. 6, 451 .

Bruce, H. M. (1966) Smell as an exteroceptive factor. 7. Anim. Sci. 25 (Suppl. 1), 83.

Dominic, G. J. (1965) The origin of the pheromone causing pregnancy block in mice. 7 . Reprod. Fert. $10,469$.

Dominic, G. J. (1966) Observations on the reproductive pheromones of mice. I. Source. F. Reprod. Fert. 11, 407.

Marsden, H. M. \& Bronson, F. H. (1964) Estrous synchrony in mice: alteration by exposure to male urine. Science, $\mathcal{N} . \Upsilon .144,3625$.

Marsden, H. M. \& Bronson, F. H. (1965) The synchrony of oestrus in mice: relative roles of the male and female environment. 7. Endocr. 32, 313.

Whitten, W. K. (1958) Modification of the oestrous cycle of the mouse by external stimuli associated with the male. Changes in the oestrous cycle determined by vaginal smears. F. Endocr. 17, 307.

Whiтten, W. K. (1959) Occurrence of anoestrus in mice caged in groups. F. Endocr. 18, 102.

Whitten, W. K. (1966) Pheromones and mammalian reproduction. In: Advances in Reproductive Physiology, Vol. 1, p. 155. Ed. A. McLaren. Logos and Academic Press, London. 